\title{
Lise Öğrencilerinde Aileden Algılanan Sosyal Destek ile Denetim Odağı Arasındaki İlişkinin İncelenmesi
}

\author{
Examination of Relationship between Perceived Social \\ Support from Family and Locus of Control among High \\ School Students
}

\section{Levent YAYCI*}

Öz: Bu araştırmada lise öğrencilerinde aileden algılanan sosyal destek ile denetim odağı arasındaki ilişki incelenmiş, ayrıca öğrencilerin aileden algıladıkları sosyal destek ile denetim odağı düzeylerinin cinsiyet, sınıf düzeyi ve anne babalarının birlikte ya da ayrı yaşıyor oluşuna göre farklılaşıp farklılaşmadığı belirlenmeye çalışılmıştır.Çalışmanın örnekleminiGiresun İli'ndeki üç genel liseden 96'sı kız, 205'i erkek olmak üzere 301 öğrenci oluşturmuştur. İlişkisel tarama modelinin kullanıldığı çalışmada ölçme araçları olarak "Aileden AlgılananSosyal Destek Ölçeği”" (ASDÖ) ve "Rotter'in İç-DişKontrol Odağ1 Ölçeği”"(RIDKOÖ) kullanılmıştır. Verilerin değerlendirilmesinde "t” testi, tek yönlü varyans analizi ve korelasyondan yararlanılmıştır. Araştırma sonucunda, öğrencilerin denetim odağı ile aileden algılanan sosyal destek puanları arasında orta düzeyde negatif yönlü bir korelasyon bulunmuştur $(\mathrm{r}=$.040).Öğrencilerin "içten, orta düzey ve dıştan denetimli” olmalarına göre, "aileden algılanan sosyal destek' puanları arasında iç denetim odağı lehine farklılaşma saptanmıştır.Araştırmadacinsiyetegöre denetim odağı ve aileden algılanan sosyal destek puanlarının kız öğrenciler lehine farklılaştığı, sınıf düzeyine göre ise denetim odağı ve aileden algılanan sosyal destek puanları arasında 9.sınıf lehine istatistiksel olarak anlamlı bir fark olduğu bulunmuştur. Öğrencilerin anne babalarının birlikte ya da ayrı yaşıyor oluşuna bağlı olarak "denetim odağı ve aileden algılanan sosyal destek" puanlarında istatiksel olarak anlamlı bir fark bir bulunmamıştır. Araştırma bulguları ilgili literatür ışığında yorumlanıp tartışılmıştır.

Anahtar Kelimeler: Aileden algılanan sosyal destek, denetim odağı, lise öğrencisi

\begin{abstract}
Current study examines the relationship between the locus of control and the perceived social support ofthe families among high school students, whilst controlling the variables of gender, grades, and whether the parents live together or not.The sample of this study was composed of totally 301 students, 96 of them female and 205 of them male students from three high schools in the province of Giresun. "Scale of Perceived Social Support from Family" (SPSSF) and "Rotter's Internal-External Locus of Control Scale" (RIELCS) were used as the measuring tools in the study in which the descriptive and cross-sectional research models were used. "t" test, one-way analysis of variance and correlation were used in evaluating the data. In consequence of the research, a mid-level and negative oriented correlation was found between the scores of locus of control and perceived social support from family of the students(r=.040).In relation tot he students having 'internal, mid-level and external locus of control', significant difference has been found on the scores of perceived social support from family in favor of internal locus of control. It was defined that the scores of locus of control and perceived social support from family by gender of the students become different in favor of the female students. A statistically significant difference was found in favor of $9^{\text {th }}$ graders between the scores of the locus of control and perceived social support from family of the students by grade level. The research findings were interpreted and discussed in the light of the relevant literature.
\end{abstract}

Keywords: Perceived social support from family, locus of control, high school student

*Yrd.Doç.Dr., Giresun Üniversitesi, Eğitim Bilimleri Fakültesi, Giresun-Türkiye, levent.yayci@giresun.edu.tr 


\section{Giriş}

Ergenlik dönemi bireyin çocukluktan çıkıp yetişkinliğin gerektirdiği sorumlulukları almaya hazırlandığ 1 bir gelişim dönemidir.Bu dönem duygusal özerklik kazanımından başlayıp kişisel özgürlüğe doğru gidilen bir süreçtir.Özerkliğin gelişimi erken gelişim dönemlerinden itibaren bireyin kendi başına bir şeyleri yapabildiğini görmesi, baş edebilmesi ve çevresinden yetkinliği ile ilgili olumlu geri bildirim alması ile olur.Özerklik, teşvik edildiği, desteklendiği bir ortamda daha kolay gelişebilir.Ergenlik, özerklik çabalarının yoğun olarak görüldüğü bir dönemdir ve başarılı bir kimlik gelişimi için özerklik yetisi ön koşuldur.Uygun ve yeterli modellerle girilen kişilerarası etkileşimler ergeninin kendini tanıması, rol modeller belirlemesi, rasyonel amaçlar geliştirmesi ve yetkinlik beklentileri geliştirmesi açısından önemlidir.

Kişisel ve kişilerarası problemlerin bazılarının çözümünde ve bireyin ruh sağlığını dengede tutabilmesinde sosyal destek sistemi önemli bir değişkendir (Yalçın, 2004; Kaziasty, 2005).Sosyal destek, zorlanmalar, kayıplar, stres yaratan durumlar ve baş etmekte güçlük çekilen yaşantılar karşısında bireyin direncini artırandış kaynaklı fiziksel, duyuşsal, bilişsel ve davranışsal yardımlardır.Bireyin diğerleriyle kuvvetli bağları olduğuna inanması ve destek sağlayacağına ilişkin bilişsel algılaması ise algılanan sosyal destektir (Kef, 1997). Aile, yakın arkadaşlar, iş arkadaşları, komşular, öğretmenler, çevrede yer alan ideolojik, dinsel veya etnik gruplar ile bireyin içinde yaşadığı toplum gibi faktörler, o bireyin sosyal destek kaynaklarını oluşturmaktadır. Belki de bu kaynaklardan en önemlisi ailedir çünkü destek ilişkileri öncelikle ailede oluşmaya başlamaktadır (Yıldırım, 1998; Çivilidağ, 2003; Yalçın, 2004).

Bireylerin stres yaratan durumlarla baş edebilmeleri ve iyi bir gelişme gösterebilmelerinde ebeveyn desteğinin ve katkısının önemi büyüktür. Aileden algılanan sosyal destek, bireylerin öznel iyi oluşlarına, kendilerine olan güvenlerinin artmasına, yaşamdaki zorluk ve değişikliklerle daha kolay baş edebilmelerine, olumlu benlik saygısı ve öz farkındalık geliştirmelerine neden olmaktadır (Barrera, Fleming ve Khan, 2004; Sacco ve Yanover, 2006; Nakigudde, Musisi, Ehnvall, Airaksinen ve Agren, 2009; Baltacı, İşleyen ve Özdemir, 2012; Öztürk, 2014).

Aileler tutumları ve çocuğun davranışlarına verdiği geri bildirimlerle davranışın sonuçlarının nasıl meydana geldiği konusunda bir referans çerçevesi oluştururlar. Davranışın sonuçlarının hangi kaynaktan geldiği denetim odağı kavramı ile ifade edilir. Denetim odağı, bireyi etkileyen sonuçların kendisinden mi yoksa dış etmenlerden mi kaynaklandığına dair inançtır. Denetim odağı bir anlamda, sonuçların davranışlara bağlı olduğu kanısıdır (Lacroix ve Assal, 1998). Bireyin kendisini etkileyen olayların daha çok, kendi denetiminde olduğu inanc1 içsel kontrol odağı, kendileri dışındaki güçlerin denetiminde olduğu inancı ise dışsal kontrol odağıdır (Rotter, 1966; Rotter,1990; Nowicki ve Cooley, 1990; Wong-McDonald ve Gorsuch, 2004; Yeşilyaprak, 2006).

İç denetimli bireyler kendini düzenleme, kişisel kontrol ve kendi kaderini tayin etme gibi niteliklere sahiptir (Amadi, 2010) ve psikolojik olarak daha dirençlidirler (Çetinkaya ve Karaırmak, 2011). Kendi yaşamlarından sorumlu olduklarını düşünürler ve buna uygun davranışlar ortaya koyarlar (Schultz ve Schultz, 2002). Dıştan denetimli bireyler ise, genel kaygıları daha yüksek, çaresizlik etkilerinden daha kolay etkilenen, başarısızlıklarını kolayca unutamayankişilerdir (Baykara, 1999). Öz-yeterlilik ve öz düzenleme gibi denetim odağ da öğrencilerin başarısını etkileyen bir motivasyon yapısıdır (Miltiadou ve Savenye, 2003; Fritson, 2008; Ghasemzadeh ve Saadat, 2011).

Denetim odağ 1 ile ilgili yapılan çalışmalardadış denetimli öğrencilerin, iç denetim odağına sahip öğrencilere göre daha fazla stres altında olduğu (Abouserie, 1994); anne babalarından şefkat gören, memnun edilen, bağımsız davranışları desteklenen öğrencilerin iç denetim odağı puanlarının diğer öğrencilerden daha yüksek olduğu (Argun, 1995); erkek öğrencilerin, kız öğrencilere göre daha dıştan denetimli olduğu (Alisinanoğlu, 2003; Amadi, 2010; Keleş, 2009); okullarında yeterli rehberlik hizmeti alanların rehberlik hizmeti almayanlardan daha içsel denetimli oldukları (Akboy, 1997); iç denetim odağına sahip çocukların, dış denetim odağına sahip olanlara oranla daha yüksek seviyede akademik başarı sahip olma eğilimi olduğu (Shammen, 2004); genel lise öğrencilerinin cinsiyet ve anne baba 
arasındaki anlaşmazlık değişkenine göre denetim odağı puanlarının farklılaştığı, anne eğitim düzeyi ve baba eğitim düzeyi değiş̧kenlerine göre ise farklılaşmadığı (Doğan ve Ceyhan, 2008) belirtilmiştir. Gültekin (2011) ise üniversite öğrencileri üzerinde yürüttüğü çalışmasında, çocukluğunda anne ve babası tarafından kabul görmüş, desteklenmiş, sevilmiş kişilerin iç denetim odaklı olduklarını rapor etmiştir.

Aileden algılan sosyal destek düzeyi ile ilgili çalışmalarda Köküsoy (2008) Endüstri Meslek Lisesine devam eden öğrencilerin ailelerinden algıladıkları sosyal desteğin istenilen düzeyde olmadığını (orta düzeyde olduğunu), Öztürk (2014) algılanan sosyal destek ile sosyal kaygı arasında negatif bir ilişki olduğunu ve erkek öğrencilerin algıladıkları sosyal destek düzeyinin kız öğrencilerden daha düşük olduğunu (Baş ve Kabasakal, 2013; Yılmazel, 2013) belirtmişlerdir.

Literatürde lise öğrencilerinde aileden algılanan sosyal desteği ve denetim odağını farklı değişkenlere göre ayrı ayrı inceleyen araştırmalar bulunurken, aileden algılanan sosyal destek ile denetim odağı arasındaki ilişkiyi inceleyenherhangi bir araştırmaya rastlanmamıştır. Öğrencilerde aileden algılanan sosyal destek ve denetim odağı düzeyini geliştirmeye yönelik çalışmaların ve çalışmalarda kullanılacak etkinliklerin doğru tespit edilip planlanabilmesi için belirtilen değişkenlerin cinsiyet, sınıf düzeyi ve anne-babanın ayrı yada birlikte oluşuna göre değişip değişmediği bilinmelidir. $\mathrm{Bu}$ nedenle çalışmada belirtilen bağımsız değişkenlere (cinsiyet, sınıf düzeyi, anne babanın birlikte yada ayrı oluşu) göre bağımlı değişkenlerde (aileden algılanan sosyal destek düzeyi ve denetim odağı düzeyi) farklılaşma olup olmadığı da araştırılmıştır.Araştırma sonuçlarının ergen aile iletişimi, ergenlerde kimlik kazanımı, sorumluluk ve özyeterlik duygusunun gelişimi ve ergen psikolojisi gibi konulara katk1 sağlayabileceği düşünülmektedir.Araştırma sonuçları ayrıca aile eğitimi ve anne-baba destek programları gibi konularda çalışan profesyonellerin çalışmalarına da yardımcı olabilir.

$\mathrm{Bu}$ araştırmada lise öğrencilerinde aileden algılanan sosyal destek ile denetim odağ arasındaki ilişki incelenmiş, ayrıca öğrencilerin aileden algıladıkları sosyal destek ile denetim odağ1 düzeylerinin bazı değişkenlere göre farkılaşıp farklılaşmadığı belirlenmeye çalışılmış; böylece lise öğrencilerine ve ailelerine sunulan psikolojik danışma hizmetlerinin niteliğinin arttırılmasına katkı sağlanması amaçlanmıştır.Bu amaçla aşağıdaki sorulara yanıt aranmaya çalışılmıştır:

1- Öğrencilerin "denetim odağı ile aileden algılanan sosyal destek" puanları arasında ilişki var midir?

2- Öğrencilerin "içten, orta düzey ve dıştan denetimli” olmalarına göre, "aileden algılanan sosyal destek' puanları arasında farklılaşma var mıdır?

3- Öğrencilerin cinsiyetlerine bağlı olarak "denetim odağı" ve "aileden algılanan sosyal destek" puanlarında bir farklılaşma var mıdır?

4- Öğrencilerin sınıf düzeylerine bağlı olarak "denetim odağı ve aileden algılanan sosyal destek" puanlarında bir farklılaşma var mıdır?

5- Öğrencilerin anne babalarının birlikte ya da ayrı yaşıyor oluşuna bağlı olarak "denetim odağ 1 ve aileden algılanan sosyal destek" puanlarında bir farklılaşma var mıdır?

\section{Yöntem}

Lise öğrencilerindeaileden algılanan sosyal destek ile denetim odağ 1 arasındaki ilişkinin incelendiği bu çalışmadailişkisel tarama modeli kullanılmıştır.Illişkisel tarama modeli, "iki ve daha çok sayıdaki değişken arasında birlikte değişim varlığını ve/veya derecesini belirlemeyi amaçlayan araştırma modelleri” şeklinde tanımlanabilir (Karasar, 2007).

\section{Çalışma Grubu}

$\mathrm{Bu}$ çalışmanın evrenini Giresun İli'ndeki tüm genel liselerin (üç lisenin) öğrencileri oluşturmaktadır. Çalışmanın örneklemini ise şans yöntemi ile rastgele seçilen 324 öğrenci oluşturmuş̧tur. Rastgele doldurma ve tam doldurmama nedenleri ile 23 öğrenciden elde edilen veriler değerlendirme dişı tutulmuştur. Çalışma 96'sı kız, 205'i erkek olmak 301 öğrenciden 
elde edilen veriler ile yürütülmüștür. Öğrencilerin $18^{\prime}$ 'inin anne ve babası ayrı yaşamakta, 283 'ünün anne ve babası ise birlikte yaşamaktadırlar. Öğrencilerden 74'ü dokuzuncu sinıfta (\%24.6), 64'ü 10.sinıfta (\%21.3), 113’ü 11.sinıfta (\%37.5) ve 50'si 12. sinıfta (\%16.6) öğrenim görmektedir.

\section{Veri Toplama Araçlart}

Aileden Algılanan Sosyal Destek Ölçeği (ASDÖ): Araştırmada ergenlerin aileden algıladıkları sosyal destek düzeyini belirlemek amaciyla orijinalini Procidano ve Heler' in (1983) geliştirdiği, uyarlamasını Eskin'in (1993) yaptığı Aileden Algılanan Sosyal Destek Ölçeği (ASDÖ) kullanılmıștır.

Ölçek 20 maddeden oluşmakta ve maddeler "Evet", "Hayır" ve "Kısmen" şeklinde yanıtlanmaktadır. Toplam puan, tüm maddelerden alınan puanların toplanmasiyla elde edilmektedir. Elde edilen puanların yüksekliği; algılanan sosyal desteğin yüksekliğini, düşüklüğü ise; algılanan sosyal desteğin düşük olduğunu göstermektedir (Korkmaz, 2013). Ölçeğin puanlanmasında, 3., 4., 16., 19., 20. maddeler için "evet" seçeneği, "0", "kısmen" seçeneği "1", "hayır" seçeneği "2" puan olarak değerlendirilmektedir. Diğer maddeler için "evet" seçeneği " 2 ", "kısmen" seçeneği "1", "hayır" seçeneği " 0 " puan şeklinde kodlanmaktadır (Başer, 2006). Ölçekte 3,4,16,19. maddeler ters ifadelerdir. Bu sorularda hayır seçeneği +1 puan almaktadır (Eskin, 1993).

Ölçeğin geçerlik çalışmasında ASDÖ ile Procidano ve Heler'in (1983) geliştirdiği Çocuklar ve Gençler için Sosyal Destek ölçeği arasında .69 korelasyon bulunmuştur (Yıldırım, 1997). Ölçeğin iç tutarlık katsayıları çeşitli çalışmalarda .85 (Eskin, 1993; Yıldırım, 1997) ve .97 (Korkmaz, 2013) bulunmuştur. Bu araştırmada Cronbach Alfa katsayıs1 .95 olarak saptanmıştır.

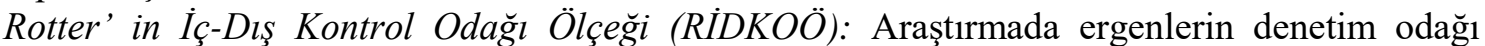
düzeyini belirlemek için Rotter'in (1966) geliştirdiği), uyarlaması Dağ $(1991 ; 2002)$ tarafından yapılan “Rotter'in İce-Dıș Kontrol Odağı Ölçeği” kullanılmıștır.

Ölçek 29 çift maddeden oluşmakta ve bireylerin genellenmiş denetim beklentilerinin içsellik-dışsallık boyutu üzerindeki konumunu saptamayı amaçlamaktadır. Her madde zorunlu seçmeli cevaplama türünde ikişer seçeneği (a ve b seçenekleri) kapsamaktadır. Altı madde ölçeğin amacını gizlemek için dolgu olarak yerleştirilmiştir ve diğer 23 maddenin dışsallık yönündeki seçenekleri 1'er puanla değerlendirilmektedir. Böylece ölçek puanları 0 ile 23 arasında değişmekte ve yükselen puan dış kontrol odağı inancının artmasına işaret etmektedir. 0-6 arasındaki puanlama içsel kontrole, 14'ün üzerindeki puanlama dışsal kontrole işaret eder. 7-13 arası ise karma-ortalama düzeye karşılık gelir (Fidan, 1986).

Ölçeğin geçerlik ve güvenirlik çalışması üniversite öğrencileri üzerinde yapılmıştır. Denetim odağı ölçeğinin yapı geçerliliği faktör analizi ile incelenmiştir. Analiz sonucunda ölçekteki maddelerin yük değerlerinin .33 ile .61 arasında değiştiği görülmüştür.Bu durum maddelerin ayırt etme güçlerine sahip oldukları göstermektedir. RiDKOÖ'nün test-tekrar test güvenirlik katsayısı ise .83'tür. Ölçeğin KR-20 tekniğiyle hesaplanan güvenirlik katsayıs1 .68, Cronbach Alfa iç tutarlık katsayısı ise .70 olarak bulunmuştur (Dağ, 1991).

Küçükkaragöz, Akay ve Canbulat (2013) tarafından üniversite öğrencileri üzerinde yapılan güncel güvenirlik çalışmalarındaCronbach Alfa içtutarlılık katsayısı .74, test tekrar test korelasyonu .69 ve iki yarı güvenirliği .60 bulunmuştur. Bu araştırmada Cronbach Alfa katsayısı .77 olarak saptanmıştır.

Kişisel Bilgi Formu: Araştırmada katılımcılara, araştırmacı tarafından hazırlanan cinsiyet, anne ve babanın birlikte yada ayrı oluşu ve sınıf düzeyini içeren soruların bulunduğu kişisel bilgi formu uygulanmıştır.

\section{Verilerin Toplanması ve Analizi}

Araştırma yüzyüze gerçekleştirilmiş olup, araştırmacı tarafından katılımcılara veri toplama araçları, araştırmanın amacı, verilerin ne amaçla kullanılacağı ve gönüllülük esası açıklanmıştır. Veri toplama araçlarının ortalama 10-15 dakika içinde yanıtlandığı görülmüştür. Verilerin 
analizinden önce yapılan genel kontrol sonucunda rastgele doldurma ve tam doldurmama nedenleri ile 23 öğrenciden elde edilen verilerin değerlendirme dışı tutulmasına karar verilmiştir.

Verilerin değerlendirilmesinde cinsiyet ve anne babanın birlikte ya da ayrı oluşu ile denetim odağ 1 ve aileden algılanan sosyal destek düzeyinin farklılaşıp farklılaşmadığ "bağımsız gruplar t testi", sınıf düzeyi ile denetim odağı ve aileden algılanan sosyal destek düzeyinin farklılaşıp farklılaşmadığı ve iç-orta-dış denetim odağı ile algılanan sosyal destek düzeyinin farklılaşıp farklılaşmadığ 1 "tek yönlü varyans analizi (ANOVA)" ve "denetim odağı" ile "aileden algılanan sosyal destek düzeyi" arasındaki ilişki korelasyon teknikleri kullanılarak değerlendirilmiş, $\mathrm{p}<0.05$ olan değerler anlamlı kabul edilmiştir.

\section{Bulgular}

Bu bölümde araştırmanın alt problemlerine cevaplar aranmış ve araştırmada kullanılan ölçeklere ilişkin istatistiki bilgilere yer verilmiştir.

Öğrencilerin denetim odağı ile aileden algılanan sosyal destek puanları arasında ilişkiyitespit etmek amacıyla yapılan Pearson Korelasyon Testi sonuçları tablo 1'de verilmiştir.

Tablo 1. Lise ÖğrencilerininDenetim Odă̆ ile Aileden Algllanan Sosyal Destek Puanlarına Göre Pearson Korelasyon Testi Sonuçları

\begin{tabular}{llll}
\hline Değişken & $\mathrm{N}$ & $\mathrm{r}$ & $\mathrm{P}$ \\
\hline $\begin{array}{l}\text { Algılanan Sosyal Destek } \\
\text { Denetim Odağı }\end{array}$ & 301 & & \\
\hline
\end{tabular}

Tablo 1 incelendiğinde, öğrencilerin denetim odağ 1 ile aileden algilanan sosyal destek puanları arasında orta düzeyde negatif yönlü bir ilişki bulunmuştur $(r=-.40 ; p<.05)$. Başka bir deyişle aileden algılanan sosyal destek puanı arttıkça denetim odağı puanı düşmektedir.

Öğrencilerin aileden algılanan sosyal destek puanlarının iç-orta ve dış denetim odağı değişkenlerine göre farklılaşıp farklılaşmadığını tespit etmek amacıyla yapılan ANOVA sonuçları tablo 2'de verilmiştir.

Tablo 2. Lise ÖğrencilerininAileden Algılanan Sosyal Destek Puanlarının Iç̧-Orta ve Dış Denetim Odă̆

\begin{tabular}{|c|c|c|c|c|c|c|}
\hline $\begin{array}{l}\text { Varyansın } \\
\text { Kaynağı }\end{array}$ & $\begin{array}{l}\text { Kareler } \\
\text { Toplamı } \\
\text { (KT) }\end{array}$ & $\mathrm{Sd}$ & $\begin{array}{l}\text { Kareler } \\
\text { Ortalamas1 } \\
(\mathrm{KO})\end{array}$ & $\mathrm{F}$ & $\mathrm{P}$ & $\begin{array}{l}\text { Anlamlı } \\
\text { Fark }\end{array}$ \\
\hline $\begin{array}{l}\text { Gruplararas1 } \\
\text { Gruplarici }\end{array}$ & $\begin{array}{l}664.069 \\
5867.651\end{array}$ & $\begin{array}{l}2 \\
298\end{array}$ & $\begin{array}{l}332.035 \\
19.756\end{array}$ & \multirow{2}{*}{16.806} & \multirow{2}{*}{.000} & \multirow{2}{*}{$\begin{array}{l}\text { İç-Orta, } \\
\text { İç-Dış } \\
\text { Orta-Dış }\end{array}$} \\
\hline Toplam & 6531.720 & 300 & & & & \\
\hline
\end{tabular}

Tablo 2 incelendiğinde öğrencilerin iç-orta ve dış denetim odağı ile aileden algılanan sosyal destek toplam puanları arasında anlamlı bir fark olduğu görülmüştür $\left[\mathrm{F}_{(2-298)}=16.806\right.$, $\mathrm{p}<.05]$. İç-orta denetim odağı arasında iç denetim odağ lehine, iç-dış denetim odağı arasında iç denetim odağı lehine, orta-dış denetim odağı arasında orta denetim odağı lehine anlamlı farklılıklara rastlanmıştır.

Lise öğrencilerinin denetim odağı puanlarının cinsiyet değişkenine göre farklılaşıp farklılaşmadığını tespit etmek amacıyla yapılant-testi sonuçları Tablo 3'de belirtilmiştir.

Tablo 3. Lise Öğrencilerinin Denetim Odă̆ı Puanlarının Cinsiyet Değişkenine Göre T-Testi Sonuçlart

\begin{tabular}{lllllll}
\hline Denetim Odağ 1 & $\mathrm{~N}$ & $\bar{X}$ & $\mathrm{~S}$ & $\mathrm{sd}$ & $\mathrm{T}$ & $\mathrm{P}$ \\
\hline Erkek & 205 & 12.55 & 3.06 & 299 & -4.23 & .00 \\
\hline
\end{tabular}




\begin{tabular}{llll}
\hline Kiz & 96 & 10.90 & 3.33
\end{tabular}

Tablo 3 incelendiğinde; erkek öğrencilerin denetim odağı puanlarının aritmetik ortalaması $(\bar{x})$ 12.55, kız öğrencilerin ise $(\bar{x}) 10.90$ olarak belirlenmiştir. Öğrencilerin cinsiyetlerine göre denetim odağı toplam puanları arasında kız ögrenciler lehine anlamlı bir fark olduğu görülmüştür [ $\left.\mathrm{t}_{(299)}=-4.23, \mathrm{p}<.05\right]$.

Öğrencilerin aileden algılanan sosyal destek puanlarının cinsiyet değişkenine göre farklılaşıp farklılaşmadığınıtespit etmek amacıyla yapılan t-testi sonuçları Tablo 4'de belirtilmiştir.

Tablo 4. Lise ÖğrencilerininAileden Algılanan Sosyal Destek Puanlarının Cinsiyet DeğişkenineGöre T-Testi Sonuçlart

\begin{tabular}{lllllll}
\hline AASD & $\mathrm{N}$ & $\bar{X}$ & $\mathrm{~S}$ & $\mathrm{sd}$ & $\mathrm{T}$ & $\mathrm{p}$ \\
\hline Erkek & 205 & 22.64 & 4.87 & 299 & 3.25 & 0.01 \\
Kiz & 96 & 24.52 & 3.94 & & & \\
\hline
\end{tabular}

Tablo 4 incelendiğinde; erkek öğrencilerin aileden algılanan sosyal destek puanlarının aritmetik ortalaması $(\bar{x}) 22.64$ kız öğrencilerin ise $(\bar{x}) 24.52$ olarak belirlenmiştir. Öğrencilerin cinsiyetlerine göre aileden algılanan sosyal destek puanları arasında kız ögrenciler lehine anlamlı fark olduğu görülmüştür $\left[\mathrm{t}_{(299)}=3.25, \mathrm{p}<.05\right]$.

Araştırmaya katılan öğrencilerin sınıf düzeyleri ile denetim odağı toplam puanlarının farklılaşıp farklılaşmadığını tespit etmek amacıyla yapılan ANOVA sonuçları Tablo 5'de verilmiş̧tir.

Tablo 5. Lise Öğrencilerinin Denetim Odă̆ Puanlarının Sinlf Düzeyi Değişkenine GöreANOVA Sonuçları

\begin{tabular}{lllllll}
\hline Varyansın Kaynağı & $\begin{array}{l}\text { Kareler } \\
\text { Toplamı } \\
(\text { KT) }\end{array}$ & sd & $\begin{array}{l}\text { Kareler } \\
\text { Ortalaması } \\
(\text { KO) }\end{array}$ & F & p & $\begin{array}{l}\text { Anlamlı } \\
\text { Fark }\end{array}$ \\
\hline $\begin{array}{l}\text { Gruplararası } \\
\text { Gruplariçi }\end{array}$ & 167.369 & 3 & 55.790 & & & $9-10$, \\
Toplam & 2977.362 & 297 & 10.025 & 5.565 & .001 & $\begin{array}{l}9-11, \\
9-12\end{array}$ \\
\hline
\end{tabular}

Tablo 5 incelendiğinde öğrencilerin sınıf düzeyleri ile denetim odağı toplam puanları arasında anlamlı fark olduğu görülmüştür $\left[\mathrm{F}_{(3-297)}=5.565 \mathrm{p}<.05\right]$. Bu fark dokuzuncu sinıf öğrencileri lehinedir. 9-10,9-11,9-12. sinıflar arasında dokuzuncu sınıf lehine anlamlı farklılık saptanmıştır. Diğer sınıflar arasında anlamlı farka rastlanmamıştır.

Lise öğrencilerinin sınıf düzeyleri ile aileden algılanan sosyal destek toplam puanlarının farklılaşıp farklılaşmadığını tespit etmek amacıyla yapılan ANOVA sonuçları Tablo 6' da verilmiştir.

Tablo 6. Lise Öğrencilerinin Aileden Algılanan Sosyal Destek Puanlarının Sinıf Düzeyi Değişkenine GöreANOVA Sonuçları

\begin{tabular}{lllllll}
\hline Varyansın Kaynağ1 & $\begin{array}{l}\text { Kareler } \\
\text { Toplamı } \\
\text { (KT) }\end{array}$ & Sd & $\begin{array}{l}\text { Kareler } \\
\text { Ortalamas } \\
\text { (KO) }\end{array}$ & F & P & $\begin{array}{l}\text { Anlaml } \\
\text { Fark }\end{array}$ \\
\hline Gruplararas1 & 210.165 & 3 & 70.055 & 3.280 & .021 & $9-10,9-11$ \\
Gruplariçi & 6321.555 & 297 & 21.357 & & & $9-12$ \\
Toplam & 6531.720 & 300 & & & & \\
\hline
\end{tabular}


Tablo 6 incelendiğinde öğrencilerin sınıf düzeyleri ile aileden algılanan sosyal destek toplam puanları arasında anlamlı fark olduğu görülmüştür $\left[\mathrm{F}_{(3-297)}=3.280 \mathrm{p}<.05\right]$. Bu fark dokuzuncu sınıf öğrencileri lehinedir. 9-10,9-11,9-12. sinıflar arasında dokuzuncu sınıf lehine anlamlı farklılık saptanmıştır. Diğer sınıflar arasında anlamlı farka rastlanmamıştır.

Öğrencilerin denetim odağı puanlarının anne babaların birlikte ya da ayrı oluşu değişkenine göre farklılaşıp farklışmadığınıtespit etmek amacıyla yapılan t-testi sonuçları Tablo 7'de verilmiştir.

Tablo 7. Lise Öğrencilerinin Denetim Odă̆ı Puanlarının Anne Babaların Birlikte ya da Ayrı Oluşu Değişkenine Göre T-Testi Sonuçlart

\begin{tabular}{lcccccc}
\hline $\begin{array}{l}\text { Anne-baba } \\
\text { birlikte olma }\end{array}$ & $\mathrm{N}$ & $\bar{X}$ & $\mathrm{~S}$ & $\mathrm{sd}$ & $\mathrm{T}$ & $\mathrm{P}$ \\
\hline Birlikte & 283 & 11.98 & 3.14 & 299 & -.86 & .39 \\
Ayr1 & 18 & 12.66 & 4.48 & 299 & \\
\hline
\end{tabular}

Tablo 7 incelendiğinde; anne-babası birlikte yaşayan öğrencilerin denetim odağ1 puanlarının aritmetik ortalaması $(\bar{x}) 11.98$, ayrı yaşayan öğrencilerin ise $(\bar{x}) 12.66$ olarak belirlenmiştir. Öğrencilerin anne-babalarının birlikte ya da ayrı yaşıyor oluşuna göre denetim odağı toplam puanları arasında anlamlı bir fark görülmemiştir [ $\left.\mathrm{t}_{(299)}=-.86, \mathrm{p}>.05\right]$.

Öğrencilerin aileden algılanan sosyal destek puanlarının anne babaların birlikte yada ayrı oluşu değişkenine göre farklılaşıp farklılaşmadığını tespit etmek amacıyla yapılan t-testi sonuçları Tablo 8'de belirtilmiştir.

Tablo 8. Lise Öğrencilerinin Aileden Algılanan Sosyal Destek Puanlarının Birlikte yada Ayrı Yaşama Değişkenine Göre T-Testi Sonuçları

\begin{tabular}{lllllll}
\hline AASD & $\mathrm{N}$ & $\bar{X}$ & $\mathrm{~S}$ & $\mathrm{sd}$ & $\mathrm{T}$ & $\mathrm{P}$ \\
\hline Birlikte & 283 & 23.31 & 4.58 & 299 & 1.02 & 0.30 \\
Ayr1 & 18 & 22.16 & 5.96 & & & \\
\hline
\end{tabular}

Tablo 8 incelendiğinde; anne-babası birlikte yaşayan öğrencilerin aileden algılanan sosyal destek puanlarının aritmetik ortalaması $(\bar{x})$ 23.31, anne-babası ayrı yaşayan öğrencilerin ise $(\bar{x}) 22.16$ olarak belirlenmiştir. Öğrencilerin cinsiyetlerine göre aileden algılanan sosyal destek puanları arasında anlamlı bir fark görülmemiştir $\left[\mathrm{t}_{(299)}=1.02, \mathrm{p}>.05\right]$.

\section{Tartışma}

Yapılan çalışmada lise öğrencilerinde aileden algılanan sosyal destek ile denetim odağ arasındaki ilişki incelenmiş ve denetim odağı ile aileden algılanan sosyal destek düzeyi arasında orta düzeyde negatif yönlü ilişki saptanmıştır. Öğrencilerin iç-orta ve dış denetim odağı ile aileden algılanan sosyal destek puanları arasında iç-orta denetim arasında iç denetim lehine, orta-dış denetim arasında orta denetim lehine ve iç-dış denetim arasında iç denetim odağ lehine anlamlı farklılıklar belirlenmiştir.Araştırma sonucunda, öğrencilerin cinsiyetleri ile aileden algılanan sosyal destek ve denetim odağı puanları arasında kız öğrenciler lehine anlamlı bir fark bulunmuştur. Öğrencilerin sınıf düzeylerine göre aileden algılanan sosyal destek ve denetim odağı puanları arasında dokuzuncu sınıf öğrencileri lehine anlamlı farklılıklar görülmüştür. Anne babanın birlikte ya da ayrı yaşıyor oluşu ile denetim odağı ve aileden algılanan sosyal destek düzeyi arasında ise anlamlı bir farklılık bulunmamıştır.

Araştırmanın ilk bulgusu öğrencilerin aileden algılanan sosyal destek puanları ile denetim odağı puanları arasında orta düzeyde negatif bir ilişki olduğudur. Aileden algılanan sosyal destek puanı arttıkça denetim odağı puanı düşmektedir. Bu durum aileden alınan sosyal desteğin bireyde diştan denetimlilikten orta düzey ve içten denetimliliğe doğru bir gelişme sağladığını göstermektedir. Araştırma bulguları ebeveynlerin çocuklarını belli konularda 
cesaretlendirmelerinin onların o konudaki sonuç beklentilerini artırmada etkili olduğu (ByarsWinston ve Fouad, 2008) ve aile desteği ile denetim odağı arasında ilişki olduğu (Işık, 2013) bulguları ile paralellik göstermektedir. Aileden algılanan sosyal destek, cesaretlendirme ve model alma öğrenme yaşantıları ile kişilerin belirli bir konudaki yetkinlik algılarını güçlendirmektedir (Lent, 2005). Yetkinlik beklentisinin gelişmesi, özgüvenin gelişmesine, kendini düzenleme kapasitesinin artmasına, kendisi ile ilgili olumlu tutum geliştirmesine ve olayların kontrolünü sağlayabileceği inancının oluşmasına katkı sağlayabilir. Aile tarafından ergene ilgi gösterilmesi, karar verme durumlarında bask1 yaşamadan düşüncelerini paylaşabileceği ve danışabileceği ebeveyn desteğinin olması, koşulsuz kabul ve saygı görmesi, ailede söz hakkının olduğunu düşünmesi, kendisini saklamadan açabileceği bir aile içi ilişkiler sisteminin olması, başarabileceği konusunda ailesinden geri bildirimler alması ve gelişim düzeyine uygun sorumluluklar verilerek özerkliğin desteklenmesi ergeninin denetim odağ düzeyini etkileyebilir.

Araştırmada ikinci olarak öğrencilerin 'içten, orta düzey ve dıştan denetimli” olmalarına göre, "aileden algılanan sosyal destek" puanları arasında farklılık olup olmadığı incelenmiş ve içten denetim odağı lehine anlamlı bir farklılık görülmüştür. Karadayı (1994) demokratik anababa tutumunun egemen olduğu ailelerde yetişen bireylerin, problemler karşısında daha az kaygı duyma, kendi başına kararlar verip bunları uygulayabilme ve daha bağımsız hareket edebilme gibi özelliklere sahip olduklarını, Öz ve Dil (2003) iç denetim odaklı öğrencilerin aile içinde önemli karar alınma sürecine katıldıklarını, Argun (1995) memnun edilen, bağımsız davranışları desteklenen ve ödüllendirilen çocukların iç denetim odağı puanlarının yüksek olduğunu, Dil ve Bulantekin (2011) ise aile içi iletişimin sağlıklı olmasının çocuğun iç kontrol odaklı olma özelliğini artıracağını ifade etmektedir. Bu sonuçlar araştırmanın bulgularını destekler niteliktedir.

Araştırmanın üçüncü bulgusu kız öğrencilerin denetim odağı puan ortalamalarının erkek öğrencilerin ortalamalarından manidar derecede yüksek olduğudur. Literatür incelemelerinde araştırma bulguları ile paralel olarak kız öğrencilerin denetim odağı puan ortalamalarının erkek öğrencilerin puan ortalamalarından yüksek olduğu (Alisinanoğlu, 2000; Doğan ve Ceyhan,2008; Amadi, 2010 ve Keleş, 2011) bulguları tutarlılık göstermiştir. Bununla birlikte denetim odağının cinsiyete göre değişmediğini (Sahranç, 2000; Güçray 2003; Bozkurt, Serin ve Emran (2004); Bohanek, Marin ve Duke (2006) gösteren araştırma bulguları da vardır.

Araştırma bulgularına göre kız öğrencilerin olayları denetimleri altına almada kendilerini daha yetkin gördükleri ve sonuçların kendi çabalarına bağlı olduğu konusundaki inançlarının daha yüksek olduğu düşünülebilir. Bu durumun nedeni kız ve erkek çocuklarının yetiştirilme tarzlarından kaynaklanabilir. Türkiye'de kızlardan büyürken ev içi işlerde erkek çocuklara göre daha çok yardım beklenmesi, daha fazla sorumluluk verilmesi, cinsiyet rolü olarak fedakarlığın vurgulanması ve çoğu kez toplumsal cinsiyet eşitsizliği ile kendi kişisel güçleri ile mücadele etmek zorunda kalmaları daha fazla çaba göstermelerine neden olabilir. Güçlükleri aşma ve sorumlukları yerine getirme konusundaki deneyimleri kız çocuklarının yetkinlik beklentilerini artırabilir. Bu durum kızların iç denetim odaklarının gelişmesine katkı sağlayabilir.

Araştırmada ortaya çıkan kız öğrencilerin aileden algıladıkları sosyal destek puanlarının daha yüksek olduğu bulgusu alanyazın (Elbir, 2000; Kartal ve Çetinkaya, 2009; Saygın ve Arslan, 2009; Akyol ve Sal1, 2013; Y1lmazel, 2013; Baran, Küçükakça ve Ayran, 2014) ile paralellik göstermektedir. Kız öğrencilerin kültürel olarak erkek öğrenciler kadar rahat sosyal ortamlarda bulunamayıp aileleri ile daha çok zaman geçirmeleri, aile ile paylaşımlarının erkeklere nazaran daha fazla olması, ailelerin kızlara daha korumacı yaklaşmasının bu sonuçları doğurduğu düşünülebilir.

Araştırmada ögrencilerin sınıf düzeylerine bağlı olarak "denetim odağı" ve aileden algılanan sosyal destek" puanlarında dokuzuncu sınıf öğrencileri lehine anlamlı farklılık görülmüştür. Diğer sınıflar arasında farklılık görülmemiştir. Araştırma bulguları Ünsar, KurtSadırlı, Demir, Zafer ve Erol (2009), Kartal ve Çetinkaya (2009) ve Karataş'ın (2012) algılanan sosyal desteğin sınıf düzeyine göre farklılaştığını gösteren bulguları ile paralellik 
göstermektedir. Dokuzuncu sınıf öğrencilerinin aileden algıladıkları sosyal destek puanın yüksek olması, öğrencilerin ortaokuldan yeni mezun olmaları ve ailelerinin çocuklarını ergen değil hala çocuk olarak görmelerinden kaynaklanabilir. Ayrıca öğrencilerin bir kısmının ergenliğe girmemeleri ve bu nedenle aileden bağımsızlaşma çabalarının görülmemesi de ögrencinin aile ile daha fazla paylaşım içerisinde olmasına ve bu nedenle daha fazla destek algilamasina neden olabilir.

Öğrencilerin anne babalarının birlikte ya da ayrı yaşıyor oluşuna bağlı olarak "denetim odağı ve aileden algılanan sosyal destek" puanlarında bir farklılığa rastlanmamıştır. Araştırma grubunda anne babası ayrı yaşayan 18 öğrenci bulunmaktadır. Örneklem azlığının daha güçlü istatistiksel sonuçlar koyabilmeyi engelleyebileceği düşünülebilir. Ayrıca ayrılma sürecinin nasıl gerçekleştiği, ayrılmanın öğrenci kaç yaşında iken gerçekleştiği ve öğrencinin her iki ebeveynle de iletişimim devam edip etmediği gibi hususların bilinmemesi bu bulguya ilişkin yorum yapmayı güçleştirmektedir.

\section{Sonuç ve Öneriler}

Alanyazında uygun koşullar sağlandığında denetim odağının dışdenetimlilikten iç denetimliliğe doğru geliştirilmesinin mümkün olduğunu ortaya koyan araştırma bulgularına rastlanılmaktadır (Odacı, Kalkan, Balcı ve Yılmaz, 2003; Sardoğan, Kaygusuz ve Karahan, 2006; Y1lan, 2007; Alpars, 2007; Selcen, 2009). İçten denetimli olma gelişimsel bir süreç olduğundan erken gelişim dönemlerinden itibaren aile içi iletişim, tutumlar, gelişim dönemleri, özgüvenli ve özsaygılı çocuk yetiştirme, destek kaynaklarının doğru kullanımı gibi konularda ebeveyn eğitimine önem verilebilir. Dış denetim odaklı öğrencilerkendilerine olan güvenlerinin gelişmesi için atılganlık eğitimi gibi konularda grup çalışmalarına alınabilir. Öğrencilerin kendilerini tanımaları ve yeteneklerini geliştirebilmeleri için okul içi ve dışında sportif ve sosyal etkinliklere katılım olanakları artırılarak yetkinlik beklentilerinin ve içten denetimlilik özelliklerinin gelişimine katkı sağlanabilir.

$\mathrm{Bu}$ çalışmanın bazı sınırlılıkları vardır. Birincisi, çalışma genel lise öğrencileri ile sınırlıdır. Bu nedenle değişik türdeki lise öğrencileri üzerinde de çalışmalar yürütülebilir, erinlik dönemi ve ergenliğin daha ileri dönemleri gibi gruplarla araştırmanın kapsamı genişletilebilir, İkincisi, çalışma öğrenci beyanları ve ölçeklerin ölçtüğü özelliklerle sınırlıdır. Son olarak çalışma cinsiyet, sınıf düzeyi ve anne-babanın ayrı ya da birlikte yaşıyor oluşu değişkenleri ile sinırlıdır. Denetim ve odağı ve aileden algılanan sosyal destek düzeyine etki edebilecek başka değişkenlerle de yeni çalışmalar yapılabilir.

Sonuç olarak, belirli sınırlılıklarına rağmen bu çalışmanın, ergenlik dönemindeki öğrencilerle çalışan öğretmen, psikolog, psikolojik danışman, sosyal hizmet uzmanı ve ruh sağlığı alanında çalışan diğer uzmanlara yapacakları çalışmalarda katkı sağlayacağı düşünülmektedir. Çalışma ayrıca ebeveyn eğitimlerinde denetim odağı ve aileden algılanan sosyal destek kavramına vurgu yapılmasının önemini de göstermektedir.

\section{Kaynaklar}

Abouserie, R. (1994). Sources and levels of stress in relation to locus of control and self-esteem in university students. Educational Psychology, 14(3), 323-330.

Akboy, R. (1997). Kuruluş amaçları, ÖSS/ÖYS ve öğretim planları çerçevesinde fen liseleri. Dokuz Eylül Üniversitesi Araştırma Projesi, İzmir.

Akyol, A.K. ve Salı, G. (2013). Yatılı ve gündüzlü okuyan çocukların benlik kavramlarının ve sosyal destek algılarının incelenmesi. Kastamonu Eğitim Dergisi, 21(4 ), 1377-1398.

Alisinanoğlu, F. (2003). Çocukların denetim odağı ile algıladıkları anne tutumları arasındaki ilişkinin incelenmesi. Türk Ĕ̆itim Bilimleri Dergisi, 1(1), 97-107.

Alpars, G. (2007). Düşünme eğitimi programının çocukların denetim odağı algılarına etkisinin incelenmesi. Yayınlanmamış yüksek lisans tezi. Konya: Selçuk Üniversitesi Sosyal Bilimler Enstitüsü.

Amadi, M. (2010). Affective determinants of ESL success. Unpublished M.Ed. Project.Ibadan: Department of Teacher Education. University of Ibadan. 
Argun, Y. (1995). Anne-babanın çocuk yetiștirme tutumlarının ortaokul öğrencilerinin denetim odağı üzerine etkileri. Yayınlanmamış yüksek lisans tezi. İzmir: Dokuz Eylül Üniversitesi Eğitim Bilimleri Enstitüsü.

Baltacı, H.Ş., İşleyen, F. ve Özdemir, S. (2012). Eğitim fakültesi öğrencilerinin romantik ilişki durumları ve sosyal ağkullanımlarına göre etkileşim kaygısı ve sosyal destek algılarının incelenmesi. Mersin Üniversitesi Eğitim Fakültesi Dergisi, 8(2), 25-36.

Baran, M., Küçükakça, G. ve Ayran, G. (2014). Sağlık yüksekokulu öğrencilerinde algılanan sosyal destek düzeyinin sigara kullanımı üzerine etkisi. ADÜ Tip Fakültesi Dergisi, 15(1), 9-15.

Barrera, M., Fleming, C.F. ve Khan, F.S. (2004). The role of emotional social support in the psychological adjustment of siblings of children with cancer. Child Care Health Development, 30(2), 103-111.

Baş, A.U. ve Kabasakal, Z. (2013).Öğretmen adaylarında umutsuzluk ve algılanan sosyal destek. Ë̆gitim ve Öğretim Araştırmaları Dergisi (Journal of Research in Education and Teaching), 2(1), 19-26.

Başer, Z. (2006). Aileden algılanan sosyal destek ile kendini kabul düzeyi arasındak iliş̧kinin incelenmesi. Yayınlanmamış yüksek lisans tezi. Erzurum: Atatürk Üniversitesi

Sosyal Bilimler Enstitüsü.

Baykara, K. (1999). İşbirliğine dayalı öğrenme teknikleri ve denetim odakları üzerine bir çalışma. Yayınlanmamış doktora tezi. Ankara: Hacettepe Üniversitesi Sosyal Bilimler Enstitüsü.

Bohanek, J.G., Marin, K., Fivush, R. ve Duke, M. (2006). Family narrative interaction and children's sense of self. Family Process, 45(1).

Bozkurt, N., Serin, O. ve Emran, B. (2004). İlköğretim birinci kademe öğretmenlerinin problem çözme becerileri, iletişim becerileri ve denetim odağı düzeylerinin karşılaştırmalı olarak incelenmesi. XII. Ĕ̈itim Bilimleri Kongresi Bildirileri. Ankara: Gazi Üniversitesi Eğitim Bilimleri Bölümü.

Byars-Winston, A.M., \& Fouad, N.A. (2008). Math and science social cognitive variables in college students:Contributions of contextual factors in predicting goals. Journalof Career Assessment, 16, 425-440.

Çetinkaya, R. ve Karaırmak, Ö. (2011). Benlik saygısının ve denetim odağının psikolojik sağlamlık üzerine etkisi: Duyguların aracı etkisi.Türk Psikolojik Danışma veRehberlik Dergisi, 4(35), 30-43.

Çivilidağ, A. (2003). Anadolu lisesi ve özel lise ögrretmenlerinin iş tatmini, iş stresi ve algllanan sosyal destek düzeylerinin karşılaştırllmasına yönelik bir analiz. Yayımlanmamış yüksek lisans tezi. İstanbul: İstanbul Üniversitesi, Sosyal Bilimler Enstitüsü.

Dağ, İ. (1991). Rotter'in iç-dış kontrol odağı ölçeği (RIDKOÖ)'nin üniversite öğrencileri için güvenirliği ve geçerliği.Psikoloji Dergisi, 7 (26), 10-16.

Dağ, İ. (2002). Kontrol odağı ölçeği (KOÖ): Ölçek geliştirme, güvenirlik ve geçerlik çalışması, Türk Psikoloji Dergisi, 17 (49), 77-90.

Dil, S. ve Bulantekin, Ö. (2011). Hemşirelik öğrencilerinde akademik başarı düzeyi ile aile işlevselliği ve kontrol odağı arasındaki ilişkinin belirlenmesi. Psikiyatri Hemşireliği Dergisi, 2(1), 17-24.

Doğan, M. ve Ceyhan, E. (2008). Genel lise öğrencilerinin aile işlevlerinin ve denetim odaklarının incelenmesi. Aile ve Toplum, 4(15), 67-82.

Elbir, N. (2000). Lise 1. sınıf ögrencilerinin sosyal destek düzeylerinin bazı değişkenler açısından incelenmesi. Yayınlanmamış Yüksek Lisans Tezi. Ankara: Hacettepe Üniversitesi Eğitim Bilimleri Enstitüsü.

Eskin, M. (1993). Reliability of the Turkish version of the perceived social support from friends and family scales, scale for interpersonal behavior, and suicide probability scale. Journal of Clinical Psychology, 49(4), 515-522.

Fidan, N. (1986). Okulda öğrenme ve ögretme. Ankara: Kadığlı Matbaası. 
Fritson, K.K. (2008). Impact of journaling on students' self-efficacy and locus of control. Journal of Scholarly Teaching, 3, 75-83.

Ghasemzadeh, A., \& Saadat, M. (2011). Locus of control in Iranian university student and its relationship with academic achievement. Procedia-Social and Behavioral Sciences, 30, 2491-2496.

Güçray, S.S. (2003). The analysis of decision making behaviors and perceived problem solving skills in adolescents. The Turkish Online Journal of Educational Technolog -TOJET, 2(2).

Gültekin, Z. (2011). Üniversite ögrencilerinin algllanan anne-baba reddiyle başetmeleri ile denetim odă̆l, öğrenilmiş güçlülük ve eş kabul-reddiyle ilişkisi. Yayımlanmamış yüksek lisans tezi. İzmir: Dokuz Eylül Üniversitesi Eğitim Bilimleri Enstitüsü.

Işık, E. (2013). Mesleki sonuç beklentisinin yordayıcıları olarak algılanan sosyal destek ve denetim odağı. Kuram ve Uygulamada Eğitim Bilimleri, 13(3), 1419-1430.

Karadayı, F. (1994). Üniversite gençlerinin algıladıkları ana-baba tutumları, ana babayla ilişkileri ve bunların bazı kişilik özellikleriyle bağlantısı. Türk Psikoloji Dergisi, 9 (32), $15-25$.

Karasar, N. (2007). Bilimsel araştırma yöntemi (17.baskı). Ankara: Nobel Yayıncılık.

Karataş, Z. (2012). Ergenlerin algılanan sosyal destek ve sürekli kaygı düzeylerinin incelenmesi. Mustafa Kemal Üniversitesi Sosyal Bilimler Enstitüsü Dergisi, 9(19), 257271.

Kartal, A. ve Çetinkaya, B.(2009). Yüksekokul öğrencilerinin algılanan sosyal destek durumları ve sosyal desteği etkileyen faktörler. Firat Sağllk Hizmetleri Dergisi, 4(12), 3-20.

Kaziasty, K. (2005). Social support and traumatic stress. The National Center for Post Traumatic Stress Disorder Research Quarterly. 16(2), 1-8.

Kef, S. (1997). The personal networks and social supports of blind and visually impaired adolescents. Journal of Visual\&Blindness, 91 (3), 236-244.

Keleş, D. (2009). Öğretmen adaylarının alan ĕgitimi ve bazı psikososyal değişkenlere göre denetim odağı eğilimleri ile ögrenme stilleri tercihleri. Yayımlanmamış Yüksek Lisans Tezi.Denizli:Pamukale Üniversitesi Sosyal Bilimler Enstitüsü.

Korkmaz, G. (2013). Akut psikiyatri servislerinde yatan hastalarda içselleştirilmiş stigma ve algllanan aile desteği. Yayınlanmamış Yüksek Lisans Tezi. İstanbul:İstanbulÜniversitesi Ruh Sağlığı ve Psikiyatri Hemşireliği Anabilim Dalı.

Köküsoy, K. (2008). Endüstri meslek liselerinde bir meslek alanına yönelmis olan öğrencilerin mesleki olgunluk ve algıladıkları aile desteği düzeylerinin incelenmesi. Yayınlanmamış yüksek lisans tezi. İstanbul: Yeditepe Üniversitesi Sosyal Bilimler Enstitüsü.

Küçükkaragöz, H., Akay, Y. ve Canbulat, T. (2013). Rotter iç-dış kontrol odağ1 ölçeğinin öğretmen adaylarında geçerlik ve güvenirlik çalışması. Akademik Bakış Dergisi, 35, 112.

Lacroix, A., \& Assal, J.P. (1998). Therapeutic education of patients. VIGOT: Paris.

Lent, R.W. (2005). A social cognitive view of career development and counseling. In S. D. Brown \& R.W. Lent (Eds.), Career development and counseling: Putting theory and research to work, 101-130). New Jersey: John Wiley \& Sons.

Miltiadou, M., \& Savenye, W.C. (2003). Applying social cognitive constructs of motivation to enhance student success in online distance education. Educational Technology Review, $11(1)$.

Nakigudde, J., Musisi S., Ehnvall, A., Airaksinen, E., \& Agren, H. (2009). Adaptation of the multidimensional scale of perceived social support in a Ugandan setting. AfricanHealth Sciences, 9, 35-41.

Nowicki, S. J. R., \& Cooley E. (1990). The role of locus of control orientation in speed of diskriminorting facial affect.Journal of Resarch Personality, 24, 389-397. 
Odac1, H., Kalkan, M., Balcı, S., ve Yılmaz, S. (2003). Sosyal beceri eğitiminin ilköğretim öğrencilerinin denetim odağı üzerine etkisi. Türk Psikolojik Danışmave Rehberlik Dergisi, 20, 49-58.

Öz, F. ve Dil, S. (2003). Hacettepe üniversitesi hemşirelik yüksekokulu I. ve IV. sınıf öğrencilerinin denetim odağını etkileyen faktörler ve eleştirel düşünme gücü ile ilişkisi. Hacettepe Üniversitesi Hemşirelik Yüksekokulu Dergisi, 2, 27-40.

Öztürk, A. (2014). Sorumluluk tutumu ve aileden algılanan sosyal desteğin sosyal kaygıyı yordamadaki rolü ve etkisi. Hacettepe Üniversitesi Eğitim Fakültesi Dergisi [Hacettepe University Journal of Education], 29(3), 137-152.

Procidano, M.E., \& Heller, K. (1983). Measures of perceived social support from friends and from family: three validation studies. Am J Community Psychol, 11(1), 1-24.

Rotter, J.B. (1966). Generalized expectancies for internal and external control of reinforcement. Psychological Monographs, 80, 1-28.

Rotter, J.B. (1990). Internal versus external control of reinforcement. American Psychologist, 45(4), 489-493.

Sacco, W.P., \& Yanover, T. (2006). Diabetes and depression: the role of social support and medical symptoms. Journal of Behavioral Medicine, 29, 550-552.

Sahranç, Ü. (2000). Lise ögrencilerinin mesleki olgunluk düzeylerinin denetim odaklarına göre bazı değişkenler açısından incelenmesi. Yayınlanmamış yüksek lisans tezi. Ankara: Hacettepe Üniversitesi Eğitim Bilimleri Enstitüsü.

Sardoğan, M.E., Kaygusuz, C. ve Karahan, T.F. (2006). Bir insan ilişkileri beceri eğitimi programının üniversite öğrencilerinin denetim odağı düzeylerine etkisi. Mersin Üniversitesi Ĕ̆itim Fakültesi Dergisi, 2(2), 184-194.

Saygın, Y. ve Arslan, C. (2009). Üniversite öğrencilerinin sosyal destek, benlik saygısı ve öznel iyi oluş düzeylerinin incelenmesi. Selçuk Üniversitesi Ahmet Keleşoğlu Ĕgitim Fakültesi Dergisi, 28, 207-22.

Schultz, D.P., \& Schultz, E.M. (2002). Modern psikoloji tarihi. (Çev: Yasemin Aslay) İstanbul: Kaknüs Yayınları.

Selcen, A. (2009). Denetim odağı ĕgitim programının ilköğretim 6. 7. ve 8. sinıf öğrencilerinin denetim odağı düzeylerine etkisi. Yayınlanmamış yüksek lisans tezi. İzmir: Dokuz Eylül Üniversitesi Eğitim Bilimleri Enstitüsü.

Shammen, N. (2004). Language attitude in multilingual primary school in Fiji. Language, Culture and Curriculum, 17 (2), 1-13.

Ünsar, S., Kurt-Sadırlı, S., Demir, M., Zafer, R. ve Erol, Ö. (2009). Üniversite öğrencilerinin sosyal destek düzeyleri ve etkileyen etmenler. Dokuz Eylül Üniversitesi Hemşirelik Yüksekokulu Elektronik Dergisi, 1(1), 17-29.

Yalçın, İ. (2004). Ailelerinden algıladlkları destek düzeyleri farklı lise öğrencilerinin saldırganlık düzeyleri. Yayınlanmamış yüksek lisans tezi. Ankara: Hacettepe Üniversitesi Sosyal Bilimler Enstitüsü.

Yeşilyaprak, B. (1988). Lise öğrencilerinin içsel ya da dışsal denetim oluşlarını etkileyen etmenler. Yayınlanmamış doktora tezi. Ankara: Hacettepe Üniversitesi Sosyal Bilimler Enstitüsü.

Yeşilyaprak, B. (2006). Eğitimde bireysel farklılıklar, (Ed: Kuzgun, Y. ve Deryakulu, D.). Ankara: Nobel Yayın Dağıtım.

Yılan, G. (2007). Psikolojik yardımın dıştan denetimli insanların iç̧en denetim düzeyini yükseltmeye etkisi. Yayınlanmamış yüksek lisans tezi. Samsun: Ondokuz Mayıs Üniversitesi Sosyal Bilimler Enstitüsü.

Yıldırım, İ. (1997). Algılanan sosyal destek ölçeği’nin geliştirilmesi güvenirliği ve geçerliği. Hacettepe Üniversitesi Ë̆itim Fakültesi Dergisi, 13, 81-87.

Yıldırım, İ. (1998). Akademik başarıdüzeyleri farklı olan lise öğrencilerinin sosyal destek düzeyleri. Türk Psikolojik Danışma ve Rehberlik Dergisi, 2 (9), 33-38.

Yılmazel, G. (2013) Sağlik Yüksekokulu öğrencilerinde algılanan sosyal destek ve sağlıkla ilişkili davranışlar. New/Yeni Symposium Journal, 51 (3), 151-157. 
Wong-McDonald, A., \& Gorsuch, R.L. (2004). A multivariate theory of god concept, religious motivation, locus of control, coping and spiritual well-being. Journal of Psychology and Theology, 32(4), 318-334.

\section{Extended Abstract}

\section{Introduction}

Current study examines the relationship between the locus of control and the perceived social support of the families among high school students, whilst controlling the variables of gender, grades, and whether the parents live together or not.

\section{Method}

The sample of this study in which the relational screeningresearch model was used, was composed of totally 301 students, 96 of them female and 205 of them male students. "Scale of Perceived Social Support from Family" (SPSSF) and "Rotter's Internal-External Locus of Control Scale" (RIELCS) were used as the measuring tools in the study.

\section{Findings}

A mid-level and negative oriented correlation was found between the locus of control of the students and the perceived social support scores from family $(\mathrm{r}=-.40)$.

It was observed that there is a significant difference between the internal-mid and external locus of control of the students and the total perceived social support scores from family $\left[\mathrm{F}_{(2-298)}=16.806, \mathrm{p}<.05\right]$. It was found that there are significant differences among the internal-mid locus of control in favor of internal locus of control, among the internal-external locus of control in favor of internal locus of control and mid-external locus of control in favor of mid-locus of control.

The arithmetic average of locus of control points of the male students were specified as $(\bar{x}) 12.55$ and of the female students as $(\bar{x}) 10.90$. It was observed that there is a significant difference among the total scores of locus of control by gender of the students in favor of the female students $\left[\mathrm{t}_{(299)}=-4.23, \mathrm{p}<.05\right]$.

The arithmetic average of perceived social support of the male students from family was specified as $(\bar{x} 22.64$ and of the female students as $(\bar{x}) 24.52$. It was observed that there is a significant difference among the perceived social support scores of the students from family by gender in favor of the female students $\left[\mathrm{t}_{(299)}=3.25, \mathrm{p}<.05\right]$.

It was observed that there is a significant difference between the class levels and total scores of locus of control of the students $\left[\mathrm{F}_{(3-297)}=5.565 \mathrm{p}<.05\right]$. This difference is in favor of the ninth-graders. A significant difference was detected among the $9^{\text {th }}-10^{\text {th }}, 9^{\text {th }}-11^{\text {th }}, 9^{\text {th }}-12^{\text {th }}$ grades in favor of $9^{\text {th }}$ grade. Any significant difference was not detected among the other grades.

It was observed that there is a significant difference between the grade levels of the students and the perceived social support from family $\left[\mathrm{F}_{(3-297)}=3.280 \mathrm{p}<.05\right]$. This difference is in favor of the ninth-graders. A significant difference was detected among the $9^{\text {th }}-10^{\text {th }}, 9^{\text {th }}$ $11^{\text {th }}, 9^{\text {th }}-12^{\text {th }}$ grades in favor of $9^{\text {th }}$ grade. Any significant difference was not detected among the other grades.

The arithmetic average of locus of control of the students whose parents live together was specified as $(\bar{x}) 11.98$ and of those whose parents are separated as $(\bar{x})$ 12.66. Any significant difference among the total scores of locus of control by whether the parents live together or are separated was not observed $\left[\mathrm{t}_{(299)}=-.86, \mathrm{p}>.05\right]$.

The arithmetic average of perceived social support scores of the students whose parents live together was specified as $(\bar{x}) 23.31$ and of those whose parents are separated as $(\bar{x}) 22.16$. Anysignificant difference among the perceived social support scores from family by gender of the students was not observed [ $\left.\mathrm{t}_{(299)}=1.02, \mathrm{p}>.05\right]$. 


\section{Discussion and Conclusion}

The first finding of the research is that there is a mid-level and negative relationship between the perceived social support scores of the students from family and locus of control. When the scores of the perceived social support from the family go up, the locus of control scores go down. This result shows that the social support received from the family results on the individual an improvement toward being extravert locus of control from being mid-level and introvert locus of control. Showing interest of the family to the adolescent, the availability of the parental support in sharing his or her thought and consulting without pressure in making decision, getting respectand clean acceptance from his or her family, thinking he/she has a voice in the family, the presence of intra-family relation systems in which she/he can open him/her without hiding his/her feelings, receiving feedbacks from his/her family in achieving and supporting autonomy by giving responsibilities suitable for his/her development levelmight affect the locus of control level of the adolescent.

Secondly, this research aimed to answer the question whether there is a difference on the scores of the perceived social support from the family in relation their being "introvert, midlevel and extravert locus of control" and significant difference has been shown in favour of internal locus of control. This result is in line with the literature showing that children who is satisfied, whose independent behaviours are supported and who is reinforced are scoring higher on internal locus of control scores.

It might be thought according to the research findings that the female students consider themselves more competent to bring the events under their controls and their beliefs in that the results depend on their own efforts are higher. The reason of this situation might arise from the upbringing of female and male children. The followings might be given as reasons for making more efforts of the girls; in Turkey, the girls are restricted more in social environments in comparison with the boys while the girls grow, more assistance is expected in the domestic works from the girls than the boys, more responsibility is given to the girls, the devotion is emphasized as the gender role and the girls are often obliged to struggle with their personal powers with the gender inequality. Girls' experiences in overcoming difficulties and fulfilling responsibilities may increase their self efficacy. This situation may contribute to the development of girls' internal locus of control.

Furthermore, the research results reveal that the social support levels of the female students perceived from their families are higher than the male students. The female students don't present in social environments as comfortable as the male students on a cultural basis, spend more time together with their families, share more with their families than the male students and the families show a more protective approach to the female students; it might be thought that all of them produce these results collectively.

It was observed in the study that there is a significant difference in favor of $9^{\text {th }}$ graders in their scores of "locus of control' and perceived social support from family" on the basis of the grade levels of the students. The high score of perceived social support from family of $9^{\text {th }}$ graders might result from the newly graduated students from the school and the families considering their children still as a child not as anadolescent. Furthermore, some of the students not hitting adolescence and therefore any effort to be independent from the family not seen might lead to sharing more with the family and therefore to perceiving more support.

No difference was found between the scores of locus of control and perceived social support from family depending on whether the parents of students living together or separately. There are 18 students in the study group, the parents of whom live separately. Small sample size may have impeded to obtain stronger statistical results. In addition, the followings might be given as reasons for making it difficult to comment on this finding; knowing no information regarding the issues such as the realization of the separation process, the age of the student when the separation process happened and communication of the student with both parents during/after the separation process.

When the proper conditions are supplied in literature, there are research findings revealing that it is possible to develop the locus of control from external control to internal 
control (Odaciet. al., 2003; Sardoğanet. al., 2006; Yılan, 2007; Alpars, 2007; Selcen, 2009). Since being internally controlled is a developmental process, the importance might be given to the parental education in the fields of intra-family communication, attitudes, and developmental periods, raising a confident and self-reliant child, correct use of support resources as of the early development periods. Students with external locus of control can be involved in group work on the subjects such as assertiveness training to develop their self-confidence. In order for students to know themselves and improve their skills, the opportunities of participation in sportive and social events inside and outside the school might be increased. This can also contribute to the development of their competence expectations and internal locus features.

In conclusion, it is thought despite the certain limitations that this study will contribute to the studies to be carried out by the teachers, physiologists, psychological counselors, social service specialists and other specialists working in the field of mental health working with the students in adolescence periods. Furthermore, the study reveals the importance to point out the notion of locus of control and perceived social support from family in parental educations. 